\title{
COMPRESSION IGNITION ENGINE INCORPORATING CONCEPT OF NANO FLUID AND EXTRACTION OF ENERGY FROM DISSOCIATION OF WATER MOLECULE
}

\author{
Punya Sloka Dash ${ }^{1}$ \\ ${ }^{I}$ B.Tech, Department of Mechanical Engineering, College of Engineering \& Technology, Bhubaneswar, India
}

\begin{abstract}
The present day scenario of the modern world is impossible to imagine without automobile. Thus it a primary challenge for automobile industries to design efficient and cost effective engine. The performance of the engine again depends on the type of fuel used, the cooling system, the lubrication system, the range of temperature in which the engine works etc. If the factors are taken care of then the performance of the engine can be improved. In this paper the effect of the fuel assimilating metallic nanoparticles is studied. After the combustion of fuel in the combustion chamber the byproducts of combustion (water vapor and carbon dioxide) are further disintegrated, the dissociation of water being an exothermal process adds up to the heat intake of the engine. The food for the engine being heat and not the fuel, it is beneficial in every sense to extract maximum possible amount of heat from the given mass of fuel. This process has both merits and demerits which are shown by the comprehensive study of the fuel used in an internal combustion engine, the chemical process involved in the combustion and the process of exhaust.
\end{abstract}

Keywords: Nanofluids, Heat Transfer, Conductivity, Knocking and Detonation, Thermal Diffusibility.

\section{INTRODUCTION}

The ever increasing demand of automobile has lead to the continuous technical advancement in this field. The performance of an engine is not only dependent on the efficiency of the engine, but also on other factors like ignition system, cooling system, transmission system, emission from exhaust and longevity of the engine. However here we will study the effect of knocking by suspending metallic nano particles in the fuel and try to decrease it. Nano fluids consist of a carrier liquid, such as water, ethylene glycol, gasoline etc dispersed with tiny nano-scale particles known as nano particles.

The suspending of metallic nanoparticles to the fuel of an internal combustion engine will decrease the specific heat of the fuel i.e; less amount of energy will be required to increase the temperature of unit mass of the fuel (formed after suspending metallic nano particle) through $1{ }^{\circ} \mathrm{C}$ as compared to the original fuel, thus making it easier to ignite the fuel.

The byproducts of clean combustion are mainly carbon dioxide and water vapor.

$2 \mathrm{C}_{8} \mathrm{H}_{18}+25 \mathrm{O}_{2} \rightarrow 16 \mathrm{CO}_{2}+18 \mathrm{H}_{2} \mathrm{O}$ (for gasoline)

$4 \mathrm{C}_{12} \mathrm{H}_{23}+71 \mathrm{O}_{2} \rightarrow 48 \mathrm{CO}_{2}+46 \mathrm{H}_{2} \mathrm{O}$ (for diesel)

Now if somehow the water vapor can be dissociated into hydrogen and oxygen, then we can utilize the heat produced by this dissociation which is an exothermal process and thereby increase the heat energy fed into the engine. Every care must be taken in the design consideration of the engine so that the products of dissociation do not recombine again, because if this happens then it will be a heat consuming process which is undesirable. The oxygen and hydrogen can be safely exhausted to the atmosphere reducing the atmospheric pollution, which is a matter of major concern these days. This process of dissociation of water or water vapor into its component elements i.e; hydrogen and oxygen is generally a difficult process, but the presence of metallic nano particles for example aluminium nano particle will make the dissociation process a impetuous process. This is the principle of hydrogen fuel cell.

\section{OBJECTIVES}

The objective is to reduce the knocking in a compression ignition type internal combustion engine and at the same time extract maximum possible amount of heat from the fuel. This is done by adding metallic nanoparticles in the fuel (diesel, in case of compression ignition engines). The suspension of metallic nano particles enables the fuel to burn fast, which is the key factor to avoid knocking. The presence of the nano particles cause the easy dissociation of water molecules which being an exothermal process adds up to the heat input of the engine.

The following are the agenda of the research:-

1) To compare the calorific value of conventional fuel of a CI engine and fuel incorporating nanoparticles experimentally.

2) To observe the mechanical wear and tear of a CI engine using fuel having nanoparticles and comparing it with that of CI engine using conventional fuel, keeping the tendency of knocking in mind.

3) To obtain a stable nano fluid by dispersing nano particles in fuel. 
4) To study the exhaust gases and their detrimental effect on environment.

5) To estimate the increase in the cost of fuel and to determine whether the plan will be economical keeping the cost and longevity of the engine in mind.

\section{GENERAL CHARACTERSTICS OF NANO}

\section{FLUIDS}

The general properties of nano fluids are:-

1) Higher heat conduction due to larger exposed surface area of the nanoparticles (the conduction heat transfer rate $\mathrm{Q}_{\text {conduction }}$ is given by:-

$\mathrm{Q}_{\text {conduction }}=\mathrm{K}$.A.dT/dx where, $\mathrm{K}=$ Thermal conductivity of the medium, which is greatly increased

due to addition of nano

particles

$$
\mathrm{A}=\text { Surface area across }
$$

which conduction is taking place

$\mathrm{dT} / \mathrm{dx}=$ Temperature

gradient

The above law is known as Fourier's Law of Conduction)

2) As the particle size decreases, the thermal conductivity increases.

3) The nano particles are so small in size that there is no risk of clogging.

4) As the size of the nano particles is very less so is their mass. Therefore their momentum is negligibly less and this phenomenon makes it impossible for the nano particles to erode the metallic parts of the engine.

5) As the nano particles weigh less, the chance of sedimentation is also very less. This makes the nano fluid more stable.

6) The thermal diffusibility of the nanofluid is high compared to that of conventional fluid. As $\alpha$ $=\mathrm{K} /\left({ }^{\circ} \mathrm{C}\right)$, where $\alpha$ is the thermal diffusibility of the fluid, $\mathrm{K}$ the thermal conductivity, $\rho$ the density of the fluid and $\mathrm{C}$ its heat capacity. Thermal diffusibility of a medium physically signifies the ability of the medium to allow the heat energy to get diffused through the medium more quickly, which is a desirable condition for compression ignition type internal combustion engines.

\section{USE OF NANO FLUID AS FUEL IN A COMPRESSION IGNITION ENGINE}

In a compression ignition type internal combustion engine, if ignition delay period is long, the quantity of fuel accumulated in the cylinder during delay period will be large, which will result in high pressure rise during uncontrolled combustion leading to the generation of high pressure wave which when strikes the cylinder produces sound. This phenomenon is known as knocking and it causes the longevity of the engine less. Thus it is desired to reduce knocking.

There is always an audible knock in the compression ignition engines so clear demarcation between normal combustion and abnormal combustion (that is knocking) is not possible.

Following factors will reduce the knocking tendency in compression ignition engines:-

1) High temperature of charge.

2) High density of charge.

3) Short ignition delay.

4) Reactive mixture.

Thus it is clear that the fuel in a compression ignition type engine must burn as fast as possible giving out energy so as to reduce knocking and hence increasing the engine longevity.

It is known that by dispersing metallic nano particles in diesel its temperature rise will be less, but it density will also increase. The heat capacity of the fuel will decrease and hence less heat is required by the fuel now for a significant rise of temperature, which will lead to shorter ignition delay. By dispersing metallic nano particles the fuel also becomes chemically reactive. Hence a compromise should be made between the various merits and demerits of suspending metallic nano particles in diesel w.r.t the knocking tendency.

The following are achievable reactions of aluminum nano particles with water:-

$$
\begin{aligned}
& 2 \mathrm{Al}+6 \mathrm{H}_{2} \mathrm{O}=2 \mathrm{Al}(\mathrm{OH})_{3}+3 \mathrm{H}_{2} \\
& 2 \mathrm{Al}+4 \mathrm{H}_{2} \mathrm{O}=2 \mathrm{AlO}(\mathrm{OH})+3 \mathrm{H}_{2} \\
& 2 \mathrm{Al}+3 \mathrm{H}_{2} \mathrm{O}=\mathrm{Al}_{2} \mathrm{O}_{3}+3 \mathrm{H}_{2}
\end{aligned}
$$

The first reaction forms the aluminum hydroxide bayerite $\left(\mathrm{Al}(\mathrm{OH})_{3}\right)$ and hydrogen, the second reaction produces the aluminum hydroxide boehmite $(\mathrm{AlO}(\mathrm{OH}))$ and hydrogen, and the third reaction forms aluminum oxide and hydrogen. All the above reactions are thermodynamically favorable from room temperature past the melting point of aluminum $\left(660^{\circ} \mathrm{C}\right)$. All the above reactions are also highly exothermic. From room temperature to $280^{\circ} \mathrm{C}, \mathrm{Al}(\mathrm{OH})_{3}$ is the most stabile product, while in the range $280-480^{\circ} \mathrm{C}, \mathrm{AlO}(\mathrm{OH})$ is most stable. Above $480^{\circ} \mathrm{C}, \mathrm{Al}_{2} \mathrm{O}_{3}$ is the most stable product.

The following table shows the thermodynamics of aluminium and water reaction:-

$$
2 / 3 \mathrm{Al}+2 \mathrm{H}_{2} \mathrm{O} \rightarrow 2 / 3 \mathrm{Al}(\mathrm{OH})_{3}+\mathrm{H}_{2}(\mathrm{~g})
$$

The reaction thermodynamics shown in the table below indicates that aluminum should spontaneously react with water. The process is also a highly exothermal process summing up to the net heat input of the engine.

\begin{tabular}{|l|l|l|l|}
\hline $\mathrm{T}\left({ }^{\circ} \mathrm{C}\right)$ & $\begin{array}{l}\Delta \mathrm{H}(\mathrm{KJ} / \mathrm{mol} \\
\left.\mathrm{H}_{2}\right)\end{array}$ & $\Delta \mathrm{S}(\mathrm{J} / \mathrm{K})$ & $\begin{array}{l}\Delta \mathrm{G}(\mathrm{KJ} / \mathrm{mol} \\
\left.\mathrm{H}_{2}\right)\end{array}$ \\
\hline 0 & -277 & 26.2 & -284 \\
\hline 100 & -284 & 3.29 & -285 \\
\hline 200 & -291 & -12.1 & -285 \\
\hline
\end{tabular}




\section{MERITS AND DEMERITS}

The following are the benefit of the purposed work:-

1) Less knocking tendency of fuel and hence the longevity of the engine is more.

2) Heat can be extracted from the dissociation of water which adds up to the total heat input of the engine.

The demerits of the proposed work are following:-

1) This concept of dispersing metallic nano particles in fuel cannot be used in spark ignition type internal combustion engines because it will cause heavy detonation.

2) The exhaust may contain the metallic nanoparticles which will cause pollution of environment.

3) The fuel will become expensive.

\section{RELEVANCE AND PROJECTED OUTPUT OF} THE PROPOSED STUDY

The relevance of the proposed study with respect to current scenario in the world is very significant. Automobile has become an important part of everyone's live without which the process of technological, economical, scientific progress is impossible. Thus it is very much desirable to improve this sector so that it can serve humanity in a more better and broader prospective.

Even though in the proposed study the problems of environmental pollution have not been focused, it is a field to which attention must be given.

The projected output of the proposed study is as follows:-

1) Less knocking in CI engine which will lead to more longevity of the engine.

2) Increased heat intake for the same quantity of fuel used, which will increase the efficiency

\section{CONCLUSION}

The automobile has become an inevitable and nonavoidable part of every human being. Hence technical development in this sector is desired. An vehicle being a costly thing for a common man, it is desired that the vehicle lasts longer. By using nano fluids as fuel in compression inginition engines the tendency of knocking is reduced, which in turn reduces the mechanical wear and tear of the engine and hence increases its longevity. Extracting energy from the dissociation of water molecule is also a good method to utilize the fuel to greater extent. Hence the compression ignition engine incorporating concept of nano fluids and extraction of energy from dissociation of water molecule will serve human race in a more efficient manner.

\section{REFERENCES}

[1] V. Ganeshan, “INTERNAL COMBUSTION ENGINES”, McGraw Hill Education(India) Private Limited.

[2] Yunus A. Cengel and Afshin J. Ghajar, "Heat and Mass Transfer”,Tata McGraw Hill Education Private Limited
[3] Sheng-Qi Zhoua_ and Rui Ni, "Measurement of the specific heat capacity of water-based Al2O3 nanofluid" ,APPLIED PHYSICS LETTERS 92, 093123 _2008_

[4] J. Karthick Raja, R. Ajeeth Rajan and M. Puviyarasan,” Thermal Aspects of Nanofluids: An Insight of Other Researchers", IOSR Journal of Mechanical and Civil Engineering (IOSR-JMCE) e-ISSN: 2278-1684,p-ISSN: 2320-334X, Volume 11, Issue 4 Ver. VIII (Jul-Aug. 2014), PP 19-27 www.iosrjournals.org

[5] R J Bhatt, H J Patel, O G Vashi, "Nano Fluids: A New Generation Coolants”, IJRMET Vol. 4, Issue 2, May October 2014

[6] http://www.eolss.net/sample-chapters/c08/e3-13-0301.pdf

[7]

https://www1.eere.energy.gov/hydrogenandfuelcells/pdfs/al uminium_water_hydrogen.pdf

[8] P K Nag,'Engineering Thermodynamics FIFTH EDITION", McGraw Hill Education(India) Private Limited NEW DELHI

\section{BIOGRAPHY}

Punya Sloka Dash is presently pursuing Bachelor in Technology degree in Mechanical Engineering from College of Engineering and Technology, Bhubaneswar, Odisha, India. He has completed a design course in CATIA software from Central Tool Room and Training Centre, Bhubaneswar. He can be contacted through the email address: punyasloka06@gmail.com. 